\title{
The Nigerian Oil and Gas Industry Content Development Act and GATT Treaty Obligations: On a Path of Harmony or Discord?
}

\author{
Uchenna Jerome Orji *
}

\begin{abstract}
The Nigerian Oil and Gas Industry Content Development Act of 2010 prescribe local content requirements to promote the patronage of Nigerian products and services by operators in the oil and gas industry. Local content requirements however appear to violate obligations under the World Trade Organization's (WTO) General Agreement on Tariffs and Trade (GATT) (1994) of which Nigeria is a member. This article examines provisions of the Act and Nigeria's obligations under the GATT with a view to determining whether the provisions of the Act are in violation of GATT obligations, and whether those violations are covered by any of the exemptions under the GATT. The article finds that sections 10(1) (a), 11(1), 12 and 13 of the Act, which favor the use of local products and materials for projects in the oil and gas industry, contravene the national treatment obligations under Article III of GATT. The article also finds section 53 of the Act to be in violation of the obligation to ensure the general elimination of quantitative restrictions under Article XI:1 of GATT. However, the article suggests that GATT exemptions justify Nigeria's application of local content measures in the industry. Nigeria can rely on Article XVIII of GATT to apply local content measures for the purpose of promoting economic development and improving living standards in the country. Besides, Nigeria can rely on Articles XII: 1/2 and XIX:1 of GATT to apply local content measures that restrict fabricated/welded metal products imports in order to prevent a serious decline in monetary reserves and also safeguard domestic producers of similar products from "serious injury" that may arise from the increased imports of such products.
\end{abstract}

Keywords: GATT; Local content requirements; Nigeria; WTO obligations; Oil and gas industry.

\section{Resumen}

El Acta de Nigeria para el desarrollo de contenido de la industria del petróleo y el gas de 2010 prescribe requisitos de contenido local para promover el uso de productos y servicios nigerianos por parte de los operadores de esta industria. Sin embargo, los requisitos de contenido local parecen violar las obligaciones del Acuerdo General sobre Aranceles Aduaneros y Comercio (GATT) (1994) de la Organización Mundial del Comercio (OMC), del que Nigeria es miembro. En este artículo se examinan las disposiciones del Acta y las obligaciones de Nigeria en virtud del GAT'T para determinar si estas disposiciones infringen las obligaciones del GATT, y si esas infracciones están cubiertas por alguna de las exenciones previstas en el Acuerdo. El análisis determina que los artículos 10 (1) (a), 11 (1), 12 y 13 del Acta, que favorecen el uso de productos y materiales locales para proyectos en la industria del petróleo y el gas, contravienen las obligaciones de trato nacional en virtud del artículo III del GATT. El trabajo también determina que el artículo 53 del Acta infringe la obligación de garantizar la eliminación general de las restricciones cuantitativas en virtud del artículo XI:1 del GATT. Sin embargo, se estima que las exenciones del GATT justifican la aplicación de medidas de contenido local en la industria. Nigeria puede basarse en el artículo XVIII del GATTT para aplicar medidas de contenido local con el fin de promover el desarrollo económico y mejorar el nivel de vida en el país. Además, Nigeria puede basarse en los artículos XII: $1 / 2$ y XIX:1 del GATT para aplicar medidas de contenido local que restrinjan la importación de productos metálicos fabricados/soldados a fin de evitar una disminución grave de las reservas monetarias y también proteger a los productores nacionales de productos similares del "daño grave" que pueda derivarse del aumento de la importación de esos productos.

Palabras claves: GATT; requisito de contenido local; Nigeria; obligaciones OMC; gas y petróleo.

\footnotetext{
* PhD in Law from Nnamdi Azikiwe University, Nigeria. Assistant Professor, School of Law, American University of Nigeria, Yola, Nigeria. Email: uchenna.orji@aun.edu.ng. Received: December, $5^{\text {th }} 2019$; accepted: May, $10^{\text {th }} 2020$.
} 
Uchenna Jerome Orji

The Nigerian Oil and Gas Industry Content Development Act and GATT Treaty Obligations: On a Path of Harmony or Discord?

\section{Introduction}

The oil and gas industry is the most strategic sector of the Nigerian economy and accounts for the largest source of the government's revenue and national export earnings (IMF, 2017, 2019; World Bank 2017). ${ }^{1}$ Despite the strategic importance of the industry to Nigeria, it appears however, that it has not been effectively integrated into the mainstream of the national economy. The government's heavy dependence on the industry as the major source of revenue has mired the country in an economic state of affairs that reflects the 'Dutch disease' or 'resource curse' phenomena. ${ }^{2}$ This has persistently manifested in form of economic distortions and the neglect of other critical sectors such as the agricultural and manufacturing sectors (Binuomote and Odeniyi, 2013). Accordingly, it has been aptly observed that:

"Petroleum has transformed Nigeria from the diversified, agro-based economy that it was up until the sixties to the mono-resource, petroleum based economy that it has become since the 1970s. While Nigeria has earned billions of dollars exporting oil and natural gas, the industry has not generated the type of multiplier effects necessary to facilitate sustainable national development and economic growth. The 'Dutch Disease' phenomenon, which traditionally afflicts natural resource dominated economies, has ravaged the Nigerian political economy". (Iledare and Suberu, 2010, p.11)

Also, Nigeria's huge revenue-receipts from the oil and gas industry have not significantly improved living standards on the average as the country still has one of the highest rates of poverty ${ }^{3}$ and one of the lowest human index levels in the world (UNDP, 2016). In addition, Nigeria's huge revenue-receipts from the industry have not resulted in huge contributions to the national Gross Domestic Product (GDP). For example, Nigeria's National Bureau of Statistics estimates that the oil and gas industry contributes about $14.40 \%$ to the national GDP, while agriculture, which has very low revenue-receipts, makes a higher GDP contribution of about $21.97 \%$ (National Bureau of Statistics, 2013). It has also been observed that out of the estimated $\$ 12$ billion annually spent on servicing the upstream sector of the oil and gas industry, "over $80 \%$ by value of work is carried out abroad, resulting therefore in an insignificant contribution to

${ }^{1}$ The oil and gas sector accounts for over $57 \%$ of total government revenues and $94 \%$ of exports. See International Monetary Fund (IMF), Nigeria -Selected Issues, IMF Country Report No. 19/93 (IMF: Washington, D.C, April, 2019), p.5; World Bank Macroeconomic and Fiscal Management Global Practice (Nigeria Team) Nigeria Bi-Annual Economic Update: Fragile Recovery, No. 1 (World Bank: Washington, D.C, - April 2017), p.15; IMF, Nigeria Selected Issues, IMF Country Report No. 17/81 (IMF: Washington, D.C, April, 2017), p.6.

2 "Dutch disease" or "Resource curse" are terms commonly used to refer to "a phenomenon in which the discovery of substantial natural resource wealth negatively affects a nation's economy. The discovery often causes sudden appreciation in the value of the nation's currency, which in turn, decreases the nation's competitiveness in the international commodity markets. This reduces the country's exports of manufactured and agricultural commodities and increases its imports. At the same time, the natural resource sector draws a substantial share of domestic resources such as labor and materials, increasing their cost to other sectors. Moreover, when the initially booming resource sector eventually declines, the non-resource-based sectors may find it difficult to recover". See Mähler, A., Nigeria: A Prime Example of the Resource Curse? Revisiting the Oil Violence Link in the Niger Delta (German Institute of Global and Area Studies Working Papers: Germany, 2010) p. 120. See also Foundation for Environmental Security and Sustainability, Oil and Gas and Conflict Development Challenges and Policy Approaches (Foundation for Environmental Security and Sustainability and United States Agency for International Development: United States, January 2006) pp.7-8.

3 The UNDP Human Development Report (2015) classifies Nigeria as one of the five countries with the largest population of people in multidimensional poverty. See UNDP, Human Development Report 2015 (UNDP: New York, USA, 2015) pp.61 \&219. 
national GDP" (Mohammed, 2009, p.2). In the light of the above, the Nigerian oil and gas industry has been aptly described as an "enclave economy" (Akindelano Legal Practitioners, n.d).

To address the above state of affairs, the Nigerian Government enacted the Oil and Gas Industry Content Development Act on 29 March, 2010.4 The Act establishes local content obligations that promote the patronage of Nigeria products and services by operators in oil and gas industry. However, such local content requirements appear to violate obligations under several multilateral agreements of the World Trade Organization (WTO) of which Nigeria is a member. One of such agreements is the General Agreement on Tariffs and Trade (GATT) (1994). ${ }^{5}$ Nigeria has been a member of the WTO since 1 January, 1995 and a Member of GATT since 18 November, $1960 .{ }^{6}$ Therefore, Nigeria has obligations to comply with principles enshrined in the GATT. Already, questions have been raised by some WTO Member States as to the compatibility of the Local Content Act with Nigeria's obligations under the GATT. For example, in April, 2015, one of the items on the agenda of the meeting of the WTO Committee on Trade - Related Investment Measures was the compatibility of the Local Content Act with WTO Agreements such as the GATT.7 Similarly, in April, 2013, this issue was one of the items on the Agenda of the meeting of the WTO's Committee on Trade Related Investment Measures at the request of the EU and the United States. ${ }^{8}$ Specific local content measures that were in issue include the requirement to grant "first consideration" to goods manufactured in Nigeria; the minimum local content requirements for specific goods such as steel plates and pipes, cables, valves, and cement, and; the mandatory use of locally welded and fabricated products. ${ }^{9}$

This article examines the provisions of the Local Content Act and Nigeria's obligations under the GATT with a view to determine whether the Act's provisions are in violation of Nigeria's GATT obligations, and whether such violations are covered by any exceptions under the GATT. The article has four sections. The first section, which includes this introduction, reviews existing literature related to Nigeria's local content measures and WTO obligations. It also discusses the meaning of local content measures and examines the relevant provisions of the Local Content Act. The second section examines the obligations of WTO Member States under the GATT and the exemptions that apply to those obligations. The third section reviews GATT disputes relating to local content measures. The fourth section undertakes a compatibility analysis of the Local Content Act with GATT obligations and their exemptions. The conclusion then follows.

\footnotetext{
${ }^{4}$ See the Nigerian Oil and Gas Industry Content Development Act (March, 2010).

${ }^{5}$ See the General Agreement on Tariffs and Trade (GATT), TS 56 (1996) Cm 3282; 33 ILM 28 (1994).

6 See WTO, 'Nigeria and the WTO', available at <https://www.wto.org/english/thewto_e/countries_e/ nigeria_e.htm $>$ last accessed on 23 July, 2020.

${ }^{7}$ See WTO - Committee on Trade-Related Investment Measures, Nigeria - Certain Measures Taken in the "Act to Provide for the Development of Nigerian Content in the Nigeria Oil and Gas Industry" of April 2010', Minutes of Meeting of the WTO Committee on Trade-Related Investment Measures held on 16 April, 2015 (G/TRIMS/M/38) (27 July, 2015), at paragraphs 111-117.

${ }^{8}$ See WTO - Committee on Trade-Related Investment Measures, Nigeria - Certain Measures Taken in the "Act to Provide for the Development of Nigerian Content in the Nigeria Oil and Gas Industry" of April 2010', Minutes of Meeting of the WTO Committee on Trade-Related Investment Measures held on 30 April, 2013 (G/TRIMS/M/34) (19 June, 2013), at paragraphs 56-62.

${ }^{9} \mathrm{Ibid}$, at paragraph 59.
} 
Uchenna Jerome Orji

The Nigerian Oil and Gas Industry Content Development Act and GATT Treaty Obligations: On a Path of Harmony or Discord?

The article suggests that some provisions of the Local Content Act are in violation of GATT obligations. In particular, the article finds that sections 10(1) (a), 11(1), 12 and 13 of the Act favor the use of local products and materials for projects in the oil and gas industry and therefore contravene the national treatment obligation under Article III of GATT. The article also finds that section 53 of the Act (which prohibits the imports of fabricated/welded metal products in the oil and gas industry) is in violation of the obligation to ensure the general elimination of quantitative restrictions under Article XI: 1 of GATT. However, the article suggests that some GATT exemptions justify Nigeria's application of local content measures in the oil and gas industry. In particular, the article suggests that Nigeria can rely on Article XVIII of GATT to apply local content measures that contravene GATT obligations for the purpose of promoting economic development and improving the standard of living in the country. It also suggests that Nigeria can rely on Articles XII: $1 / 2$ and XIX: 1 of GATT to apply local content measures that restrict the imports of fabricated/welded metal products in the oil and gas industry. This in order to prevent a serious decline in monetary reserves and safeguard domestic producers of similar products from "serious injury" that may arise from the increased imports of such products.

There are several earlier works that analyzed the Nigerian Local Content Act and the challenges to its implementation in the oil and gas industry (Nwaokoro, 2011, Balouga, 2012, and Orji, 2014). There are also several works that have discussed the compatibility of some of the Local Content Act's requirements with WTO instruments such as the Agreement on Subsidies and Countervailing Measures (Orji, 2017a), the General Agreement on Trade in Services (Orji, 2017 b), and the Trade Related Investment Measures (Orji, 2018a). However, those earlier works did not specifically undertake an in-depth legal analysis on the compatibility of Nigeria's GATT obligations with the Local Content Act. As such, this article addresses this gap by specifically undertaking an analysis of the Act and its compliance with GATT obligations.

\section{The Concept of Local Content Measures}

Local content measures is a term that commonly classifies domestic trade measures established by States with the aim of compelling firms operating within their jurisdiction to deliberately utilize products or services that have a local origin (Orji, 2018a). Such domestic trade measures are usually imposed by States on firms in order to facilitate the achievement of national economic objectives that may include the promotion of economic diversification; the reduction of import dependency; the promotion of indigenous participation in strategic economic sectors; the promotion of exports; the facilitation of technology transfers (Orji, 2018b); skills acquisition and job creation; and the advancement of social and environmental objectives, such as the promotion of sustainable trade investments in host communities.

Local content measures usually have a double-edged sword effect depending on how they are applied in any given State. For example, there is a great probability that the application of local content measures can produce positive and sustainable economic results when they are carefully applied with a view to improving the competitiveness of local industries and not as a mechanism for shielding such industries from market competition. The application of local content measures may not produce desirable and sustainable economic outcomes where such measures are not accompanied by efforts to boast the competitiveness of local firms (Orji, 2018a). As such, there is a probability that the application of local content measures without enhancing the competitiveness of local firms who are benefiting from such 
measures may only provide a temporary and artificial protection of local firms, as they may likely become uncompetitive in the long term (UNCTAD, 2007). Therefore, it is important that a State's imposition of local content measures in a given industry is purposefully and effectively applied in a manner that enhances the long term competitiveness of local firms (Orji, 2018a).

\section{An Overview of the Nigerian Oil and Gas Industry Content Development Act}

Following Nigeria's return to civil rule in 1999, the Federal Government took steps to establish a comprehensive policy that would promote local content development in the oil and gas industry (Mohammed, 2009). The government identified that local content development in the industry required "an exhaustive systemic approach that would assess local content levels, identify constraints, develop clear policies and processes to stimulate growth [and] clearly define the roles and responsibilities of stakeholders" (p.2)..$^{10}$ This led to the development of the Nigerian Oil and Gas Local Content Policy and the subsequent enactment of the Nigerian Oil and Gas Industry Content Development Act of 2010 (Local Content Act). ${ }^{11}$ The Act applies to all matters relating to local content development in "all operations or transactions carried out in or connected with the Nigerian oil industry" (Sections 1 \& 6 Local Content Act).

A major objective of the Local Content Act is to domestically trap oil and gas industry expenditure within the Nigerian economy, to reduce massive capital flight arising from heavy reliance on foreign products and services within the industry. Therefore, the Act establishes legal obligations that encourage the patronage of Nigerian products and services ${ }^{12}$ in the industry with a view to promote indigenous participation, the transfer of technologies, and the diversification of the sources of investment in the industry. In so doing, the Act aims to leverage the industry as a catalyst for rapid and sustainable national economic growth in Nigeria. Thus, the Act promotes 'value-addition' to the Nigerian economy through local raw materials, products and services in order to stimulate the growth of indigenous capacity in the industry (Ogunyomi, et al, 2010). In addition, the Act provides for the establishment of fiscal incentives to promote the development of domestic capacity for the manufacturing of goods and provision of services imported into the industry (Section 48 Local Content Act). ${ }^{13}$ The Act also establishes an institutional framework known as the Nigerian Content Development and Monitoring Board (NCDMB) to coordinate and monitor the implementation of the Act (Section 4 Local Content Act). A core mandate of the NCDMB is to ensure "a measurable and continuous growth of Nigerian content in all oil and gas arrangements, projects, operations, activities or transactions in the Nigerian oil and gas industry" (Section 5 Local Content Act).

\footnotetext{
10 See SNF, Enhancement of Local Content in the Upstream Oil \& Gas Industry in Nigeria, SNF Report (2003) cited in Kabir A. Mohammed, Nigerian Content Development: The Petroleum Technology Development Fund Initiatives', Petroleum Technology Development Journal (July, 2009) Vol. 2.

${ }^{11}$ See the Nigerian Oil and Gas Industry Content Development Act (March, 2010). [Hereafter, Local Content Act].

${ }^{12}$ For an analysis of local content measures that promote the use of Nigerian services and the compatibility of those measures with WTO instruments, See Uchenna Jerome Orji, 'Assessing the Conformity of Nigeria's Local Content Act with GATS Obligations’, International Trade Law \& Regulation (2017) Vol. 23, Issue 1, pp.12-24.

${ }^{13}$ For an analysis of fiscal incentive regime under the Local Content Act and its compatibility with WTO instruments, see Uchenna Jerome Orji, 'The WTO Agreement on Subsidies and the Fiscal Incentive Regime under the Nigerian Local Content Act: a Compatibility Assessment', International Energy Law Review (2017) Vol. 35, Issue 5, pp.143-147.
} 
Uchenna Jerome Orji

The Nigerian Oil and Gas Industry Content Development Act and GATT Treaty Obligations: On a Path of Harmony or Discord?

\section{$\underline{\text { Local Content Obligations }}$}

The Local Content Act requires all regulatory actors and operators in the oil and gas industry to consider "Nigerian content" (local content) in the execution of operations or projects in the industry. In this respect, section 2 of the Act provides that:

"All regulatory authorities, operators, contractors, subcontractors, alliance partners and other entities involved in any project operation, activity or transaction in the Nigerian oil and gas industry shall consider Nigerian content as an important element of their overall project development and management philosophy for project execution" (Section 2 Local Content Act, emphasis added).

Thus, the Act classifies "local content" with the concept of "Nigerian content" - which it defines as the "quantum of composite value added to or created in the Nigerian economy by a systematic development of capacity and capabilities through the deliberate utilization of Nigerian human and material resources and services in the Nigerian petroleum industry" (Section 106 Local Content Act).

The Act requires that Nigerian independent operators should be given priority in commercial activities and projects for which contracts are to be awarded in the oil and gas industry (Section 3(1) Local Content Act). Section 3(2) of the Act provides that indigenous Nigerian companies are to be exclusively considered for the execution of oil and gas contracts where such companies demonstrate evidence of basic qualifications such as the ownership of equipment, the availability of Nigerian personnel and the possession of capacity to execute projects on land and swampy areas. The Act does not provide a definition of a "Nigerian independent operator" in the oil and gas industry. However, it defines an "operator" as "the Nigerian National Petroleum Company (NNPC), its subsidiaries and joint venture partners and any Nigerian, foreign or international oil and gas company operating in the Nigerian oil and gas industry under any arrangement" (Section 106 Local Content Act). The above definition of an "operator" broadly covers almost every company that operates in the Nigerian oil and gas industry irrespective of whether such company has a domestic or foreign origin. As such, the Act aims to enhance the level of "Nigerian content" or local content in the activities carried out in the oil and gas industry regardless of the origin of the company carrying out the activity. Under section 106 of the Act a "Nigerian company" is defined as a "company formed and registered in Nigeria in accordance with the provisions of the Companies and Allied Matters Act with not less than 51\% equity shares held by Nigerians". Therefore, from a joint reading of the definition of an "operator" and a "Nigerian company" under section 106 of the Act, it can be inferred that a "Nigerian independent operator" implies a Nigerian company that is operating in the oil and gas sector.

Section 53 of the Act prohibits the imports of welded products into Nigeria where such products are used for projects in the oil and gas industry. However, operators and contractors in the industry are required to carry out all their fabrication and welding activities in the country. Section 68 of the Act establishes penalties for non-compliance with local content requirements. In this regard, an operator or contractor that fails to comply with local content obligations with respect to a particular project in the oil and gas industry will be liable on conviction to a fine of $5 \%$ of the value of that project or to a cancellation of such project. 
The Local Content Plan

An operator that is bidding for any license, permit or interest in the Nigerian oil and gas industry is required to submit a "Nigerian content plan" (local content plan) to the NCDMB demonstrating compliance with requirements under the Local Content Act (Section 7 Local Content Act). An operator is also required to submit such a plan to the NCDMB before carrying out any project in the oil and gas industry (Section 7 Local Content Act). Generally, the minimum level of local content in any commercial activity or project to be executed in the oil and gas industry is required to be consistent with the levels established in the Schedule to the Local Content Act (Section 11(1) Local Content Act). Where the NCDMB is satisfied that a local content plan complies with the Act, it will issue a "certificate of authorization", authorizing the operator to execute a specific project or transaction in the oil and gas industry (Section 7 Local Content Act).

\section{The First Consideration principle}

Under the Local Content Act, every local content plan is required to contain provisions that would ensure that "first consideration shall be given to services provided from within Nigeria and to goods manufactured in Nigeria, and [that] Nigerians shall be given first consideration for training and employment in the work program for which the plan was submitted" (Section 10(1) Local Content Act, emphasis added). This requirement emphasizes the principle of first considering Nigerian products and services above all others when executing any project in the oil and gas industry and thus, it establishes a mandate known as the first consideration principle (Orji, 2014). Section 12 of the Act requires operators to submit detailed local content plans to the NCDMB showing how will comply with the Act's requirements in terms of giving first consideration to the utilization of Nigerian products and services in the oil and gas industry (Orji, 2014). Section 13 of the Act also requires that a local content plan should contain a detailed plan on how an operator or its alliance partner "intends to ensure the use of locally manufactured goods where such goods meet the specifications of the industry" (Section 13 Local Content Act, emphasis added). Apparently, the aim of requiring operators to submit such plans is to show how they are complying with the minimum levels of local content, which are prescribed in the Schedule to the Local Content Act.

\section{The General Agreement on Tariffs and Trade (GATT) and its Obligations}

The GATT establishes trade rules that apply only to trade in goods. Its obligations require Member States to desist from applying national measures that discriminate against foreign products in order to grant protection to similar products that have a domestic or local origin. Therefore, GATT obligations apply to local content measures because such measures promote the use of products that have a domestic or local origin while discriminating against similar products that have a foreign origin. Major obligations that are established under the GATT include the national treatment obligation and the obligation to eliminate quantitative restrictions. These obligations and the exemptions that Member States can apply to justify their non-compliance, are discussed in the subsections below.

\section{The National Treatment Obligation}

Article III of the GATT imposes a national treatment obligation on Member States. In this respect, Article III: 1 provides that: 
Uchenna Jerome Orji

The Nigerian Oil and Gas Industry Content Development Act and GATT Treaty Obligations: On a Path of Harmony or Discord?

“...internal taxes and other internal charges, laws, regulations and requirements affecting the internal sale, offering for sale, purchase, transportation, distribution or use of products, and internal quantitative regulations requiring the mixture, processing or use of products in specified amounts or proportions should not be applied to imported or domestic products so as to afford protection to domestic production" (Article III: 1 GATT, 1994).

The GATT's national treatment obligation also requires every Member State not to subject imported products from other GATT Members to any direct or indirect taxes or charges that are not applicable to similar products of a domestic origin (Article III: 2 GATT, 1994). However, where Member States impose internal taxes or other forms of charges on imported or domestic products, the national treatment obligation requires that such measures should not be imposed in a manner that would afford protection to domestic production (Article III: 2 GATT, 1994). In addition, Article III: 4 of the GATT requires Member States not to apply trade measures such as internal taxes or charges as well as laws, regulations or other requirements that will discriminate against imported products in order to provide advantage or protection to domestic production. Accordingly, the national treatment obligations imply that every GATT Member State shall accord a uniform treatment to both its domestic products and similar products that are imported from other GAT'T Members.

National Treatment Obligations relating to Quantitative Regulation

Article III: 5 of the GATT require GATT Member States not to establish or maintain:

"any internal quantitative regulation relating to the mixture, processing or use of products in specified amounts or proportions which requires, directly or indirectly, that any specified amount or proportion of any product which is the subject of the regulation must be supplied from domestic sources...” (Article III: 5 GATT (1994).

The above obligation prohibits a GATT Member State from establishing or maintaining any quantitative regulation that requires industries within its territory to use any specified amounts or proportion of domestically sourced materials in the manufacturing or processing of products so as to protect or grant advantage to domestic production (Article III: 5 GATT (1994). As such, it guarantees that firms will have a broad range of sources from which they can obtain materials for production, and also ensures that their choice of supply are not restricted by measures compelling them to obtain a proportion of their materials for production from domestic sources. GATT Member States are also required not to apply quantitative regulations in a manner that may specially allocate any quantities of products/materials to be sourced from foreign markets. ${ }^{14}$ Thus, in line with the principles under the national treatment obligations, GATT Member States are required not to establish or maintain regulations that will favor or discriminate among any external sources of material supply for the purpose of manufacturing or processing products.

14 See Article III: 7 of GATT which provides that: "no internal quantitative regulation relating to the mixture, processing or use of products in specified amounts or proportions shall be applied in such a manner as to allocate any such amount or proportion among external sources of supply". 
Latin American Journal of Trade Policy 7 (2020) - Universidad de Chile

Special Exemptions to National Treatment Obligations

There are exemptions that apply to the national treatment obligations under Article III of GATT. In this respect, Article III: 8 (a) of GATT provides that national treatment obligations "shall not apply to laws or requirements governing the procurement by governmental agencies of products purchased for governmental purposes". However, this exemption does not apply to products purchased by government agencies where such products will be commercially resold, or where such products are meant to be used in the production of goods for commercial sale (Article III: 8 (a) GATT, 1994). National treatment obligations do not also apply to subsidies exclusively paid by a Member State to domestic producers, including payments made to domestic producers from the proceeds of internal taxes or charges (Article III: 8 (b) GATT, 1994). Subsidy programs implemented by GATT Member States through the purchase of domestic products by government agencies are also exempted from the national treatment obligations under Article III of the GATT (Article III: 8 (b) GATT, 1994).

\section{Obligations to Ensure the General Elimination of Quantitative Restrictions}

Article XI: 1 of GATT imposes an obligation on Member States to ensure the general elimination of quantitative restrictions. This obligation requires Member States not to impose trade measures such as import or export quotas for the purpose of prohibiting or restricting the imports of any product from any GATT Member, or the exports of any product to the territory of any GATT Member. However, a GATT Member is permitted to impose fiscal measures including duties, taxes or other charges on such products (Article XI: 1 GATT (1994). In line with the national treatment obligations under Article III of GATT, it is implied that such fiscal measures (duties, taxes or other charges) would not be applied in a manner that is discriminatory against foreign products, or for affording protection to similar products with a local origin. Thus, the obligation to ensure the general elimination of quantitative restrictions prohibits a GATT Member State from imposing import or export restrictions on products being imported into its territory or being exported from its territory for protecting domestic production. The GATT permits a Member State to derogate from the obligation to eliminate quantitative import restrictions where such restrictions are necessary "[to] safeguard its external financial position and its balance of payments..." (Article XII:1 GATT, 1994). However, such restrictions are limited to preventing a serious decline in the Member's monetary reserves and achieving a reasonable rate of increase in monetary reserves (Article XII: 2 GATT, 1994).

\section{General Exemptions to Obligations under the GATT (Articles XVIII and XIX)}

The GATT establishes several exemptions which a WTO Member State can apply to derogate from complying with GATT obligations. Such exemptions include the provisions enshrined in Articles XVIII, XIX, XX and XXI of the GATT. Article XVIII of GAT'T provides for governmental assistance to development. It recognizes that the attainment of the GATT's objectives in Member States will be facilitated by the progressive development of their economies, especially for Members whose economies are still in the early stages of development and can only support low standards of living (Article XVIII: 1 GATT, 1994). Therefore, such Member States are allowed to apply measures including the maintenance of tariff protection for the establishment of a particular industry, and the application quantitative restrictions for balance of payment purposes in order to implement economic programs and policies that are designed to raise the standard of living (Article XVIII: 2 GATT, 1994). Thus, Article XVIII of the 
Uchenna Jerome Orji

The Nigerian Oil and Gas Industry Content Development Act and GATT Treaty Obligations: On a Path of Harmony or Discord?

GATT permits a WTO Member State whose economy is in the early stages of development and can only support low standards of living to "temporally" deviate from complying with GATT obligations for implementing economic measures that will raise the standard living of its people (Article XVIII: 4(a) GATT, 1994). However, the application of that exemption is subject to requirements such as the negotiation of the infringing economic measures with other WTO Members (Article XVIII: 4(a) GATT, 1994).

Exemptions due to "Unforeseen Developments" that threaten "Serious Injury" to Domestic Production

Article XIX of the GATT establishes exemptions for the application of Emergency Action on the imports of particular products. In this respect, Article XIX: 1 (a) of GATT exempts a WTO Member State from complying with GATT obligations where "unforeseen developments" and the effect of such obligations has resulted in an increase in imports of any product in a manner that would cause or threaten "serious injury" to domestic producers of a similar competing product in the territory of that Member State (Article XIX: 1(a) GATT, 1994). The decision in the early GATT matter of US — Fur Felt Hats, ${ }^{15}$ classified unforeseen developments as "developments... which it would not be reasonable to expect that the negotiators of the country making the concession could and should have foreseen at the time when the concession was negotiated". ${ }^{16}$ In the matter of Argentina - Footwear (EC), the WTO's Appellate Body interpreted the phrase "as a result of unforeseen developments" under Article XIX: 1(a) of the GATT to imply "the developments which led to a product being imported in such increased quantities and under such conditions as to cause or threaten to cause serious injury to domestic producers must have been unexpected"17. Similarly, in the matter of Korea - Dairy, the WTO Appellate Body held that the phrase "as a result of unforeseen developments" under Article XIX: 1(a) of the GATT implies developments that led to a product being imported in such quantities and under such conditions as to cause or threaten to cause serious injury to domestic producers must have been "unexpected". ${ }^{18}$ According to the Appellate Body "unforeseen developments" are developments not foreseen or expected when Members incurred that obligation. Thus, "such emergency actions [safeguard measures] are to be invoked only in situations when, as a result of obligations incurred under the GATT 1994, an importing Member finds itself confronted with developments it had not foreseen or expected when it incurred that obligation". ${ }^{19}$

\footnotetext{
${ }^{15}$ See Report on the Withdrawal by the United States of a Tariff Concession under Article XIX of the General Agreement on Tariffs and Trade (October, 1951) at paragraph 9. See also WTO, WTO Analytical Index Guide to WTO Law and Practice - GATT 1994, XXI. Article XIX, Paragraph B at 816, available at <https://www.wto.org/english/res_e/booksp_e/analytic_index_e/ analytic_index_e.htm> last accessed on 23 July, 2020.

16 Ibid.

17 See Appellate Body Report, Argentina - Safeguard Measures on Imports of Footwear, AB-1999-7, WT/DS121/AB/R (14 December 1999) at paragraph 91 (emphasis added). For a brief summary of the matter, see WTO Legal Affairs Division, WTO Dispute Settlement One Page Case Summaries 1995-2011 (WTO: Geneva, 2012) p.48.

18 See Appellate Body Report, Korea - Definitive Safeguard Measure on Imports of Certain Dairy Products, WT/DS98/AB/R, (14 December 1999) at paragraph 84. For a brief summary of the matter, see WTO Legal Affairs Division, WTO Dispute Settlement One Page Case Summaries 1995-2011 (WTO: Geneva, 2012) p.39.

${ }^{19}$ See Appellate Body Report, Korea - Definitive Safeguard Measure on Imports of Certain Dairy Products, at paragraph 86.
} 
However, a WTO Member State that is invoking the exemption of "unforeseen developments" under Article XIX: 1(a) of GATT is required to provide a "reasoned and adequate explanation" of how existing facts support its determination for the application of those exemptions. ${ }^{20}$ In particular, such WTO Member is required to demonstrate that identified unforeseen developments have resulted in the increased imports of the specific products subject to the exemption under Article XIX: 1(a) of GATT. ${ }^{21}$ Also, the factual demonstration of unforeseen developments must relate to the specific product(s) covered by the specific exempting measure(s) at issue. Hence, "the demonstration of unforeseen developments must be performed for each product [that is] subject to a safeguard measure". ${ }^{22}$

The GATT does not provide a definition of the phrase "increased quantities". However, under Article 2.1 of the WTO Agreement on Safeguards, ${ }^{23}$ the phrase apparently classifies a situation whereby a product is being imported into a WTO Member's territory "in such increased quantities, absolute or relative to domestic production, and under such conditions as to cause or threaten to cause serious injury to the domestic industry that produces like or directly competitive products". The GATT does not also define the meaning of "serious injury", however, under Article 4.1 (a) of the Agreement on Safeguards "serious injury" is defined to mean "a significant overall impairment in the position of a domestic industry". ${ }^{24}$ While the "threat of serious injury" is defined to mean "serious injury that is clearly imminent" (Article 4.1 (b) Agreement on Safeguards, 1994). Article 4.1 (b) of the Agreement on Safeguards also requires that the determination of the existence of a threat of serious injury "shall be based on facts and not merely on allegation, conjecture or remote possibility".

A Member State that is relying on the exemptions under Article XIX: 1(a) of GATT is entitled to do so to the extent and period that is necessary to prevent or remedy injury to its domestic producers. ${ }^{25}$ However, the exercise of those exemptions by a Member State is subject to conditions such as the notification of other WTO Members, and also affording opportunity for consultations with WTO Members who are the exporters of the product in issue (Article XIX: 2 GATT, 1994). Nevertheless, a Member State may apply the exemptions without prior consultation where a delay would cause damage that will be difficult to repair on the condition that consultations will be undertaken thereafter (Article XIX: 2 GATTT, 1994).

\footnotetext{
${ }^{20}$ See Appellate Body Report, United States - Definitive Safeguard Measures on Imports of Certain Steel Products, WT/DS248/AB/R, WT/DS249/AB/R, WT/DS251/AB/R, WT/DS252/AB/R, WT/DS253/AB/R, WT/DS254/AB/R, WT/DS258/AB/R, WT/DS259/AB/R, (10 November, 2003) at paragraphs 276, 279, 296, 376, 383, 399, 452, 461,472, 473, 474, 482, 487, 513(a) and (b). For a brief summary of the matter, see WTO Legal Affairs Division, WTO Dispute Settlement One Page Case Summaries 1995-2011 (WTO: Geneva, 2012) p.100.

${ }^{21}$ See Appellate Body Report, United States - Definitive Safeguard Measures on Imports of Certain Steel Products, at paragraphs 316 and 319. See also WTO Panel Report, Argentina - Definitive Safeguard Measure on Imports of Preserved Peaches, WT/DS238/R, (14 February 2003) adopted on 15 April 2003, DSR 2003:III, 1037.

22 See Appellate Body Report, United States - Definitive Safeguard Measures on Imports of Certain Steel Products, at paragraphs 319 and 322 .

${ }^{23}$ See Article 2.1 of the Agreement on Safeguards (1994).

${ }^{24}$ See Article 4.1 (a) Agreement on Safeguards (1994). Under Article 4(1) (c) of the Agreement on Safeguards, a "domestic industry" is defined to mean "the producers as a whole of the like or directly competitive products operating within the territory of a Member, or those whose collective output of the like or directly competitive products constitutes a major proportion of the total domestic production of those products".

${ }^{25}$ See Article XIX: 1(a) GATT (1994).
} 
Uchenna Jerome Orji

The Nigerian Oil and Gas Industry Content Development Act and GATT Treaty Obligations: On a Path of Harmony or Discord?

\section{General and Security Exemptions to GATT Obligations (Articles XX and XXI)}

\section{General Exemptions}

Article XX of GATT establishes broad "general exceptions" to GATT obligations. In this respect, a WTO Member State may refrain from fulfilling its GATT obligations where such measure is necessary for the protection of public morality, or for the protection of human life or health or the lives or health of animals or plants (Article XX (a) \& (b) GATT, 1994); or where such measure relates to the imports or exports of gold or silver (Article XX (c) GATT, 1994); or where such measure is "necessary to secure compliance with laws or regulations" which are not inconsistent with the provisions of the GATT (Article XX (d) \& (e) GATT, 1994); or where such measure is imposed for the purpose of conserving exhaustible natural resources (Article XX (g) GATT, 1994); or where such measure is meant to restrict the exports of domestic materials necessary to ensure the availability of essential quantities of such materials to a domestic processing industry (Article XX (h) \& (i) GATT, 1994); or where such measure is essential to ensure the acquisition or distribution of products in short supply, provided that WTO Members are entitled to an equitable share of the international supply of such products (Article XX (j) GATT, 1994).

\section{Security Exemptions}

Article XXI of GATT establishes broad exemptions to GATT obligations where the fulfillment of such obligations conflict with a Member State's security interests (Article XXI (a) GATT, 1994). Thus, a WTO Member is exempted from complying with GATT obligations where it would adversely affect its national security. ${ }^{26}$ A WTO Member is also exempted from complying with GATT obligations in a time of war, or in a period of emergency or crisis in international relations (Article XXI (b) (iii) GATT, 1994); or for the purpose of protecting its essential security interests relating to fissionable materials, traffic in arms, or for the purpose of supplying a military establishment (Article XXI (b) (i)-ii GATT, 1994). A WTO Member may also refrain from fulfilling its GATT obligations where such action is in pursuance of its obligations to maintain international peace and security under the United Nations Charter (Article XXI (c) GATT, 1994). For example, a WTO Member may impose quantitative trade restrictions including foreign exchange restrictions against another Member in compliance of a United Nations economic sanction.

\section{An Overview of GATT Disputes Relating to Local Content Measures}

One of the first GATT Panel decisions on local content requirements was rendered in the matter of Canada - Administration of Foreign Investment Review. ${ }^{27}$ The dispute arose following the United States challenge of the implementation of Canada's Foreign Investment Review Act (FIRA). Canada through the FIRA had imposed local content obligations on foreign investors, which required them to: (1)

\footnotetext{
${ }^{26}$ For an extensive discussion on GATT security exemptions, see Michael J. Hahn, "Vital Interests and the Law of GATT: An Analysis of GATT's Security Exception”, Michigan Journal of International Law (1991) Vol. 12(3), pp.558-620; Roger P. Alford, “The Self-Judging WTO Security Exception”, Utah Law Review (2011) No.3, pp. $697-759$.

${ }^{27}$ See Canada - Administration of the Foreign Investment Review Act, Report of the Panel adopted on 7 February 1984 (L/5504 - 30S/140), available at < https://www.wto.org/english/tratop_e/dispu_e/82fira. pdf > last accessed on 23 July, 2020.
} 
purchase goods of Canadian origin in preference to imported goods or in specified quantities, or to purchase goods from Canadian sources; and, (2) to manufacture goods in Canada which would otherwise have been imported. The United States contended that the local content requirements gave a discriminatory and less favorable treatment to imported products while favoring similar products with a Canadian origin; and that the local content requirements under the FIRA were inconsistent with Canada's national treatment obligations under Article III of GATT. The GATT Panel agreed with the submission of the United States that the FIRA's obligations which required the purchase of goods of Canadian origin were "requirements" within the meaning of Article III:4 of GATT, because those obligations were enforceable by the Canadian government against defaulters in Canadian courts. The Panel also found that the FIRA obligations had the effect of subjecting imported products to a less favorable treatment contrary to Article III.4 of GATT.

Another GATT Panel decision on a trade dispute that relates to local content requirements was rendered in the matter of United States Measures Affecting the Importation, Internal Sale and Use of Tobacco. ${ }^{28}$ The matter was brought against the United States by tobacco producing countries including: Argentina, Brazil, Canada, Chile, Colombia, El Salvador, Guatemala, Thailand, and Zimbabwe. These countries required the GATT Panel to determine whether the United States domestic tobacco content requirement under section 1106 (a) of the 1993 Budget Act was in violation of Article III: 5 of GATTT. Section 1106 (a) of the Budget Act had established a scheme known as the Domestic Marketing Assessment (DMA) which contained a quantitative regulation requiring manufacturers of tobacco in the United States to certify annually that they used at least $75 \%$ of domestic tobacco in producing cigarettes. A tobacco manufacturer that failed to comply with the requirement was subject to sanctions such as monetary penalties. The complaining countries argued that the DMA's imposition of financial penalties on defaulting tobacco manufacturing firms had the effect of prohibiting such firms from using more than $25 \%$ of the tobacco annually imported into the United States and that such measures violated Article III: 5 of the GATT.

In addition, the DMA's requirement that firms use a minimum $75 \%$ of locally sourced tobacco was considered a violation of Article III: 1 of GAT'T which provides that domestic "quantitative regulations requiring the mixture, processing or use of products in specified amounts...should not be applied to imported or domestic products so as to afford protection to domestic production". This was because the DMA's minimum requirement on the use of local tobacco permitted the unlimited use of domestic tobacco above the prescribed $75 \%$ without penalty, but established substantial penalties for the use of imported tobacco above the prescribed 25\%. The GATT Panel ruled that the DMA was a regulation within the meaning of Article III: 5 of GATT as it was enacted by the United States Congress and implemented through regulations made by the United States Department of Agriculture. The GATT Panel was also of the opinion that the DMA was an internal quantitative regulation since it explicitly established a requirement for the use of $75 \%$ of domestically grown tobacco in the production of cigarettes in the United States. The Panel ruled that the requirement violated Article III.5 of GATT and recommended the United States to take steps to bring the DMA into conformity with the GATT (Ayine, 2012).

\footnotetext{
${ }^{28}$ See United States - Measures Affecting the Importation, Internal Sale and Use of Tobacco, Report of the Panel adopted by the Council on 4 October 1994 (DS44/R), available at <https://www.wto.org/english/ tratop_e/dispu_e/94tobaco.pdf > last accessed on 23 July, 2020.
} 
Uchenna Jerome Orji

The Nigerian Oil and Gas Industry Content Development Act and GATT Treaty Obligations: On a Path of Harmony or Discord?

In the matter of India - Measures Affecting the Automotive Sector, ${ }^{29}$ the Indian Ministry of Commerce issued a notice which required any automobile manufacturer that wanted to import automotive components into India to enter into a Memorandum of Understanding (MoU) with the Indian Director General of Foreign Trade. However, the MoU had the effect of imposing indigenization (local content) and trade balancing requirements on India's automotive sector. Thus, the MoU required automobile manufacturers to use a minimum amount of local parts and components, and imposed a "trade-balancing condition" on manufacturers to ensure that their exports were balanced to their imports over a given period of time. Consequently, Members of States of the European Community and the United States requested the constitution of a WTO Panel to determine whether the measures imposed by India were in violation of Articles III, VI and XVIII of GATTT. However, while the dispute was pending before the WTO Panel, India modified the local content measures in issue. Nevertheless, the Panel went ahead and made a finding that India had violated GATT obligations. The WTO Panel concluded that India's indigenization requirements violated national treatment obligations under Article III: 4 of GATT as the indigenization requirements modified the conditions for competition in the Indian market to the detriment of imported automobile parts and components. The Panel also found that India's trade balancing requirements which limited the amount of imports in relation to an export commitment, acted as a restriction on imports contrary to Article XI: 1 of GATT. In addition, the Panel found that the trade balancing obligations, which were imposed on the purchasers of imported components in the Indian market, created a disincentive to the purchase of imported products while favoring domestic products, contrary to Article III: 4 of GATTT. 30

In the matter of Canada - Renewable Energy Dispute, ${ }^{31}$ Japan and the European Union (EU) brought complaints before the WTO concerning certain measures relating to local content requirements in the "Feed-in-Tariff Programme" (FIT Programme) established by the Canadian province of Ontario. ${ }^{32}$ The FIT Program required renewable energy generation facilities to use domestically produced equipment for energy generation if such facilities wished to receive guaranteed prices under the FIT Program. The complaints alleged that local content requirements under this program violated the national treatment obligations under Article III: 4 of GATT. The WTO Panel found that local content requirements under the FIT program violated national treatment obligations under Article III: 4 of GATT, since the it accorded a less favorable treatment to imported equipment while favoring the use of locally produced equipment in renewable generation facilities. 33

\footnotetext{
${ }^{29}$ See India - Measures Affecting the Automotive Sector, WT/DS146/R, WT/DS175/R and corr. 1, adopted 5 April 2002: V. 1827, available at <https://www.wto.org/english/traptop_6/dispu_e/146_175r _e.pdf> last accessed on 23 July, 2020. For a brief summary of the matter, see WTO Legal Affairs Division, WTO Dispute Settlement One Page Case Summaries 1995-2011 (WTO: Geneva, 2012) p.60.

30 See WTO Legal Affairs Division, WTO Dispute Settlement One Page Case Summaries 1995-2011 (WTO: Geneva, 2012) p.60.

31 See WTO Panel Report, Canada - Certain Measures Affecting the Renewable Energy Generation Sector, WT/DS426/R (19 December, 2012). See also Appellate Body Report, Canada - Certain Measures Affecting the Renewable Energy Generation Sector, WT/DS412/AB/R; Canada - Measures Relating to the Feed - in Tariff Program, WT/DS426/AB/R (6 May, 2013).

32 Japan filed complaints against Canada on the 13 September, 2010, while the European Union filed a similar complaint on 11 August, 2011.

33 See WTO Panel Report, Canada - Certain Measures Affecting the Renewable Energy Generation Sector, WT/DS412/R (19 December, 2012) at paragraph 7.167.
} 


\section{The Local Content Act and GATT's National Treatment Obligations - A Compatibility Analysis}

In order to determine whether obligations under the Local Content Act are in violation of the GATT's national treatment obligations, it will be necessary to determine the following:

(1) whether the Local Content Act applies to trade in goods within the oil and gas industry;

(2) whether the obligations under the Act have the effect of conferring an advantage to goods that have a domestic origin, while discriminating against foreign goods;

(3) whether the obligations under the Act have the effect of quantitative regulations that require the supply of specified products or materials from domestic sources, and;

(4) whether or not such obligations are covered by the exemptions under the GATT treaty.

Following the overview of the Local Content Act in the first section of this article, it can be seen that the Act applies not only to the provision of services, but also to the use of domestic goods in the Nigerian oil and gas industry. For example, section 1 of the Act provides that the Act "...shall apply to all matters pertaining to Nigerian content in respect of all operations or transactions carried out in or connected with the Nigerian oil and gas industry" (Section 1 Local Content Act (emphasis added). Apparently, the phrase "all operations or transactions" 34 has the effect of giving the Act a very broad scope of application, which would cover any form of business activity in the oil and gas industry including the provision of goods. The definition of local content (Nigerian content) under section 106 of the Act states that "quantum of composite value added to or created in the Nigerian economy by a systematic development of capacity and capabilities through the deliberate utilization of Nigerian ... material resources ... in the Nigerian oil and gas industry" 35 . This provides a background from which it can be inferred that the Act applies to the use of Nigerian goods since the classification of "material resources" broadly includes raw materials and unfinished products used in processing goods or products within the oil and gas industry. Section 3(1) of the Local Content Act also provides a basis from which it can be said that the Act applies to goods. The section declares that "Nigerian independent contractors shall be given first consideration ... in all projects for which contracts [are] to be awarded in the Nigerian oil and gas industry..." (Section 3(1) Local Content Act, emphasis added). In this respect, it is imperative to note that projects for which contracts can be awarded in the industry broadly include the provision of goods.

The existence of the first consideration principle under section 10(1) (a) of the Local Content Act also shows that the Act applies to goods and explicitly confers an advantage on goods manufactured in Nigeria. This because it declares that an operator's local content plan "shall contain provisions intended to ensure that first consideration shall be given to...goods manufactured in Nigeria" (Section 10(1) (a) Local Content Act, emphasis added). Another provision that indicates the application of the Local Content Act to goods is found in section 11(1) which provides that the minimum level of local content in any project to be executed in the Nigerian oil and gas industry "shall be consistent with the level set in the Schedule to [the] Act". The Schedule to the Act sets the minimum level of local content that is required with respect to the procurement and use of Nigerian products. In this respect, the Act prescribes the following (Table 1) as the minimum local content requirement for the utilization of Nigerian products in the execution of projects in the oil and gas industry.

\footnotetext{
34 A 'transaction' is defined as “the act or an instance of conducting business or other dealings". See The Blacks' Law Dictionary (8th Edition), p. 1535.

35 See Section 106 Local Content Act (emphasis added).
} 
Uchenna Jerome Orji

The Nigerian Oil and Gas Industry Content Development Act and GATT Treaty Obligations: On a Path of Harmony or Discord?

Table 1: Level of Local Content Requirement(s) in the Utilization of Materials for Projects in the Oil and Gas Industry

\begin{tabular}{|l|l|l|}
\hline S/N & Description of Materials /Products & $\begin{array}{l}\text { Minimum Level of Local Content } \\
\text { Requirement }\end{array}$ \\
\hline 1 & Steel plates, flat sheets, sections & $100 \%$ tonnage \\
\hline 2 & Steel pipes & $100 \%$ tonnage \\
\hline 3 & Low voltage cables & $90 \%$ length \\
\hline 4 & High voltage Cables & $45 \%$ length \\
\hline 5 & Valves & $60 \%$ \\
\hline 6 & Drilling mud-Baryte, Bentonite & $60 \%$ tonnage \\
\hline 7 & Cement (Portland) & $80 \%$ tonnage \\
\hline 8 & Cement (Hydraulic) & $60 \%$ tonnage \\
\hline 9 & Heat exchangers & $50 \%$ number \\
\hline 10 & Steel ropes & $60 \%$ tonnage \\
\hline 11 & Protective paints & $60 \%$ tonnage \\
\hline 12 & Glass Reinforced Epoxy (GRE) pipes & $60 \%$ tonnage \\
\hline
\end{tabular}

Source: authors' elaboration.

As shown in the above table, the contents of the Schedule to the Local Content Act clearly indicate that the Act applies to materials and products and favors the use of materials/products with a Nigerian origin. This has an implied effect of discriminating against the use of imported materials/products for the execution of projects in the oil and gas industry. Besides, the requirement under section 13 of the Act that a local content plan should contain a detailed plan on how an operator or its alliance partner "intends to ensure the use of locally manufactured goods where such goods meet the specifications of the industry", 36 has an implied effect of favoring the use of locally manufactured goods over imported goods for the execution of projects in the oil and gas industry. In addition, the Act's establishment of penalties for noncompliance with local content requirements ${ }^{37}$ (such as the utilization of local materials/products for projects in the oil and gas industry) has the effect of favoring the use of local materials/products above similar items that have a foreign origin. However, such favorable treatment of local materials/products by the Act apparently violate the GATT's national treatment obligations (Articles III: 1 and III: 4), which require the equal treatment of both domestic and foreign products/materials by WTO Member States. This can be seen in the cases of Canada - Administration of Foreign Investment Review, ${ }^{38}$ Canada Renewable Energy Dispute, ${ }^{39}$ and India - Measures Affecting the Automotive Sector, ${ }^{40}$ discussed in the previous sections of this article.

${ }^{36}$ See Section 13 Local Content Act (emphasis added).

${ }^{37}$ See Section 68 Local Content Act.

${ }^{38}$ See Canada - Administration of the Foreign Investment Review Act, Report of the Panel adopted on 7 February 1984 (L/5504 - 30S/140), available at < https://www.wto.org/english/tratop_e/dispu_e/82fira.pdf > last accessed on 23 July, 2020.

${ }^{39}$ See WTO Panel Report, Canada - Certain Measures Affecting the Renewable Energy Generation Sector, WT/DS426/R (19 December, 2012). See also Appellate Body Report, Canada - Certain Measures Affecting the Renewable Energy Generation Sector, WT/DS412/AB/R; Canada - Measures Relating to the Feed - in Tariff Program, WT/DS426/AB/R (6 May, 2013).

${ }^{40}$ See India - Measures Affecting the Automotive Sector, WT/DS146/R, WT/DS175/R and corr. 1, adopted 5 April 2002: V. 1827, available at <https://www.wto.org/english/traptop_6/dispu_e/146_175r _e.pdf > last 
The classification in Table 1 also shows that the Act's local content requirements have the effect of a quantitative regulation, which violates national treatment obligations under Article III: 5 of GATT. This is because the Act explicitly mandates the utilization of a specified proportion (percentage) of materials/products from domestic sources during the execution of any project in the oil and gas industry. These quantitative requirements appear similar to those in the case of United States Measures Affecting the Importation, Internal Sale and Use of Tobacco ${ }^{41}$ previously discussed. The Act however, does not subject imported products to any of the direct or indirect taxes or charges that are not applicable to similar products with a domestic origin. Therefore, the requirements under the Act do not appear to violate the national treatment obligation under Article III: 2 of GATT.

Having shown that the Act's local content requirements are in violation of the national treatment obligations under Articles III:1, III:4 and III:5 of GATT, the article will now turn to examine whether the Act's requirements are covered or justified by any exemptions to GATT's national treatment obligations. As seen from the previous sections, the GATT's national treatment obligations does not apply to materials or products procured by a government for non-commercial purposes, (Article III: 8 (a) GATT, 1994) and neither do they apply to government subsidies granted to domestic producers, or to the purchase domestic products by government agencies (Article III: 8 (b) GATT, 1994). These exemptions, however, cannot be applied to justify local content requirements established under the Act. This is because those requirements were specifically established to apply to commercial activities in the oil and gas industry and not for the purpose of regulating the government's procurement of product/materials for non-commercial purposes in the industry or for the purpose of granting subsidies to domestic producers in the industry.

\section{Local Content Measures and GATT's Obligation to Ensure the General Elimination of Qualitative Restrictions (Article XI: 1)}

In order to determine whether provisions of the Local Content Act are in violation of Article XI: 1 of GATT, which requires WTO Member States to ensure the general elimination of quantitative restrictions, it will be necessary to examine whether the Act establishes any provision that constitutes a quantitative restriction on the importats or exports of a material/product, and whether the application of such restrictions are exempted under the GATT. As seen from the previous sections of this article, the obligation to ensure the general elimination of quantitative restrictions requires WTO Members not to impose import or export quotas for the purpose of prohibiting or restricting the imports or exports of any product from any other WTO Member. It is also implied from the GATT's national treatment obligations that quantitative restrictions are not be used by Member States as a mechanism for favoring domestic products. Section 53 of the Local Content Act however, appears to impose a quantitative restriction by prohibiting the imports of fabricated/welded metal products. The section declares that:

accessed on 23 July, 2020. For a brief summary of the matter, see WTO Legal Affairs Division, WTO Dispute Settlement One Page Case Summaries 1995-2011 (WTO: Geneva, 2012) p.60.

${ }^{41}$ See for e.g., United States - Measures Affecting the Importation, Internal Sale and Use of Tobacco, Report of the Panel adopted by the Council on 4 October 1994 (DS44/R). 
Uchenna Jerome Orji

The Nigerian Oil and Gas Industry Content Development Act and GATT Treaty Obligations: On a Path of Harmony or Discord?

"as from the commencement of this Act, all operators, project promoters, contractors and any other entity engaged in the Nigerian oil and gas industry shall carry out all fabrication and wielding activities in the country" (Section 53 Local Content Act).

Under Article XI:2 of GATT, the obligation to ensure the general elimination of quantitative restrictions does not apply to: (i) export prohibitions or restrictions temporally applied to prevent critical shortages of foodstuffs; (ii) import and export restrictions necessary to the application of regulations for the classification or marketing of commodities in international trade; and (iii) import restrictions on any agricultural and fisheries product necessary for the enforcement of certain governmental measures. None of the above exemptions can be applied to justify the import restriction measure under section 53 of the Local Content Act. However, there are other applicable exemptions that can justify it.

Thus, Article XII: 1 and 2(a) of GAT'T creates further exemptions on the application of quantitative restrictions by Member States. In this regard, a Member State is permitted to derogate from the obligation to eliminate quantitative import restrictions where such measure is necessary "[to] safeguard its external financial position and its balance of payments..." (Article XII: 1 GATT, 1994). This in order to prevent a serious decline in monetary reserves and achieve a reasonable rate of increase in monetary reserves (Article XII: 2 (a) GATT, 1994). Nigeria can justify the application of import restrictions on fabricated/welded metal products in the oil and gas industry (section 53 Local Content Act) on the basis that such measure is necessary to safeguard its balance of payments in order to prevent a serious decline in external monetary reserves or to achieve a reasonable rate of increase in external monetary reserves. This is because Nigeria has low external monetary reserves when compared alongside other oil producing countries, or countries classified as emerging economies, or countries with similar GDP sizes (Proshare, 2017).

In addition, it has been observed that Nigeria's external monetary reserves cannot withstand the stress test for evaluating if external reserves can provide an adequate buffer in the event of an external or domestic economic crisis, such as global financial crises, natural disasters, wars, commodity price falls, domestic instability or financial crises affecting major trading partners (Proshare, 2017). This challenge arises because Nigeria heavily depends on the oil and gas industry as the major source of foreign exchange earnings (IMF, 2019, IMF, 2017 \& World Bank, 2017). Therefore any major shocks to the industry such as low oil prices or the disruption of production which are very common in industry ${ }^{42}$ will have a negative effect on Nigeria's external monetary reserves and result in the rapid depletion of the reserves if imports are to be sustained (Proshare, 2017). Such state of affairs will destabilize Nigeria's domestic currency and further cause economic recession in the country, while also making it very difficult to further sustain essential imports or attract foreign investments or loans for developmental projects (Proshare, 2017). Therefore, the fact that Nigeria's economy can probably suffer a full blown recession due to low oil prices or the disruption of oil production, apparently justifies the need for relying on Article XII: 1 and 2 of GATT. This to apply import restriction measures on fabricated/welded metal products in the oil and gas industry (section 53 of the Local Content Act), for the purpose of safeguarding the country's external financial position and increasing external monetary reserves or preventing a decline in such reserves, so

42 See United States Energy Information Administration, 'Nigeria', (26 May, 2016), available at <https://www.eia.gov/beta/international/analysis.php?iso=NGA> last accessed on 23 July, 2020. 
to enhance the country's capacity to provide adequate buffers against external or domestic economic crisis.

Import restrictions, which are applied under Article XII: 1 and 2 of GATT, are required not to exceed those measures which are "necessary" for the purpose of safeguarding a Member State's external financial position and increasing its external monetary reserves or preventing a decline in such reserves. ${ }^{43}$ More importantly, a Member State is required to "progressively relax" such restrictions as its external financial position improves, and also eliminate them when existing conditions no longer justify their application (Article XII: 2 (b) GATT, 1994). Therefore, if Nigeria is to rely on the exemptions under Article XII: 1 and 2 of GATT as a basis for imposing necessary restrictions on the imports of fabricated/welded metal products into oil and gas industry (section 53 of the Local Content Act), such restrictions would have to be progressively relaxed as the country's external monetary reserves improves. Such import restrictions will also have to be eliminated when existing conditions that no longer require their application. For example, such restrictions may have to be eliminated when Nigeria substantially increases its external financial position and its balance of payments, and achieves a reasonable rate of increase in its monetary reserves when compared alongside other oil producing countries, or countries classified as emerging economies, or countries with similar GDP sizes.

\section{Local Content Measures and the Exemptions under Articles XVIII, XIX, XX and XXI of the GATT}

Improving Low Living Standards (Article XVIII)

As seen in the previouys sections, Article XVIII permits a WTO Member, whose economy is in the early stages of development and can only support low standards of living to temporarily derogate from complying with GATT obligations, for the purpose of implementing economic development programs, to raise the standard of living of its citizens (Articles XXIII: 1, XVIII: 2, \& XVIII: 4(a) GATT (1994). This exemption can justify measures established in the Local Content Act. In this respect, it is imperative to note that Nigeria qualifies as a country whose economy is "in the early stages of development". Under the GATT, this concept is used is to classify WTO Members who "have just started their economic development" and Members whose economies "are undergoing a process of industrialization to correct an excessive dependence on primary production" (Annex I, Ad Article XVIII.2 GATT, 1994). Thus, while Nigeria is classified as a "developing country", ${ }^{44}$ its economy is not diversified, but rather reliant on the oil and gas sector which provides the major source of government revenue, accounting for over $57 \%$ of government revenues and 94\% of export earnings (IMF, 2019, IMF, 2017 \& World Bank, 2017). Therefore, it is to address this state of affairs that the Local Content Act aims to promote the patronage of local products and services in the oil and gas industry in order to integrate the industry into the mainstream of the Nigeria economy, and thereby enhance its contribution to national economic development. As such, the Local Content Act aims to leverage the oil and gas industry to facilitate the diversification of the Nigerian economy. In addition, it is imperative to note that Nigeria is classified as

\footnotetext{
43 See Article XII: 2 (a) GATT (1994).

44 See The United Nations, 'Country Classification', (2014) available at <https://www.un.org/en/ development/desa/policy/wesp/wesp_current/2014wesp_country_classification.pdf> last accessed on 23 July, 2020.
} 
Uchenna Jerome Orji

The Nigerian Oil and Gas Industry Content Development Act and GATT Treaty Obligations: On a Path of Harmony or Discord?

having one of the highest rates of poverty in the world ${ }^{45}$, which implies that the country's economy can only support "low standards of living". This state of affairs apparently justifies the application of local content measures in the oil and gas industry, because the primary aim for applying such measures is to promote economic development and generally improve the standard of living in Nigeria.

$\underline{\text { Safeguarding Domestic Producers from "Serious Injury" (Article XIX: 1) }}$

The exemption under Article XIX: 1 of GATT permits a WTO Member to derogate from GATT obligations by applying restrictions on the imports of particular products in order to safeguard domestic producers of similar products from "serious injury" that may arise from the increased imports of such products. This exemption may be applied to justify the prohibition of imported fabricated/welded metal products for use in the oil and gas industry under section 53 of the Local Content Act. This is because metal fabrication is regarded as "probably the most developed manufacturing area in the Nigerian petroleum industry" given that for several years, many structures and parts have been fabricated in the country (Balouga, 2012). In this regard, Nigeria has recorded milestones in the fabrication of complex metal and steel projects in the industry (Agbayi \& Chawai, 2009), such as the successful construction of the Bonga Buoy (the world's largest buoy) by Niger Dock (an indigenous Nigerian company) in the deep offshore waters of the Bonga; Oil Fields in the Niger Delta (Balouga, 2012) and other similar success stories of fabrication by indigenous companies (Orji, 2014, Agbayi \& Chawai, 2009). However, increased imports of fabricated/welded metal products for use in the oil and gas industry would threaten "serious injury" to the domestic producers of such products (Vaaland, et al, 2012) and thereby result in a loss of domestic manufacturing capacity (Agbu, 2007).

Nigeria's reliance on the exemption under Article XIX: 1 of GAT'T will however be subject to conditions including the notification and consultation of other WTO Members on the application of import restrictions on fabricated/welded metal products (Article XIX.2 GATT, 1994). In addition, Nigeria will have to factually demonstrate, in line with the principles in the cases of US - Fur Felt Hats, Argentina - Footwear (EC), and Korea - Dairy, both the occurrence of developments it had not "foreseen" or "expected" when it entered into GAT"T obligations ("unforeseen developments"), and that the effect of those obligations has resulted in increased imports of fabricated/welded metal products in the oil and gas industry in a manner that would cause or threaten "serious injury" to domestic producers of similar products (Article XIX: 1(a) GATT, 1994). In this regard, Nigeria will have to show the existence of a significant overall impairment on domestic producers of fabricated/welded metal products in the industry or a clearly imminent threat of such impairment arising from the increased imports of such products in the industry (Article 4.1 (b) of the Agreement on Safeguards, 1994).

\footnotetext{
45 According to the UNDP, about 54.8 percent of Nigeria's population is classified as being in multidimensional poverty, while 30 percent of its population is classified as being in "severe multidimensional poverty". See The United Nations Development Programme (UNDP), Human Development Report 2016: Human Development for Everyone (UNDP: New York, USA, 2016), p.219. See also, UNDP, Human Development Report 2015 (UNDP: New York, USA, 2015) p.61.
} 
Exemptions under Articles XX and XXI of the GATT

As seen from the previous sections, the GATT exempts WTO Members from fulfilling their treaty obligations in specific instances that are covered by the "general exceptions" (Article XX). Under the Article XX, a WTO Member is permitted to derogate from GATT obligations such as the national treatment obligation and the obligation to ensure the general elimination of quantitative restrictions. This situation where such derogation is necessary to achieve objectives such as the protection of public morals, the protection of human life or health and the lives of animals or plants, or to ensure compliance with laws or regulations, which are not inconsistent with the GATT, or to ensure the conservation of exhaustible natural resources where such measures are made effective in conjunction with restrictions on domestic production or consumption (Article XX GATT, 1994). However, none of the exemptions under Article XX of GATT can be applied to justify measures in the Local Content Act, because there is no provision under the Article that permits the derogation of GATT obligations for the sake of local content measures. Although, it may be appealing to attempt an imaginative interpretation of the exhaustible natural resources exemption under Article XX (g) of GATT to apply to measures under the Local Content Act. However, such interpretation does not appear possible because the objectives of the Local Content Act do not include the imposition of measures to conserve exhaustible natural resources through restrictions on domestic production or consumption.

As previously seen, a WTO Member may rely on the exemptions under Article XXI of GATT (security exceptions) to derogate from the national treatment obligation and the obligation to ensure the general elimination of quantitative restrictions. A WTO Member may also rely on the security exceptions to decline the provision of information on its local content measures where it considers that such disclosure is contrary to its essential security interests. The security exceptions also allow a W'TO Member to derogate from GATT obligations where such derogation is necessary for the protection of its essential security interests relating to fissionable materials or traffic in arms and ammunition or in a time of war. However, these exceptions cannot be applied to justify measures under the Local Content Act because the objectives of the Act do not relate to any of the security exceptions under the GATT.

\section{Concluding Remarks}

This article has attempted to show that while measures under the Local Content Act appear to violate Nigeria's GATT obligations, there are justifiable grounds for applying such measures under GATT exemptions. In this regard, Nigeria's local content measures can be justified under the GATT for purposes such as promoting economic development and improving the standard of living in the country; or for safeguarding the country's external financial position and preventing a serious decline in external monetary reserves; or for safeguarding domestic producers of fabricated/welded metal products from "serious injury" that may arise from the increased imports of such products in the oil and gas industry. However, Nigeria will also have to consider the progressive relaxation of such measures when the existing conditions no longer require their application. Such as when the country's external financial position improves and achieves a reasonable rate of increase in its monetary reserves, compared alongside to other oil producing countries, or countries classified with similar economic indexes, or when domestic producers of fabricated/welded metal products in the oil and gas industry are no longer under a threat of serious injury due to the increased imports of such products in the industry. Nevertheless, it is imperative that local content measures in the industry are purposefully and effectively applied in a manner 
Uchenna Jerome Orji

The Nigerian Oil and Gas Industry Content Development Act and GATT Treaty Obligations: On a Path of Harmony or Discord?

that enhances the long-term competitiveness of local firms. This approach will prevent undesirable outcomes that may arise where the application of local content measures acts as a temporary or artificial protection for local firms as such measures will likely make them uncompetitive in the long-term.

\section{References}

Agbayi E., and Chawai, E., (2009), 'Nigeria LNG Commitment to the Development of Nigerian Technological Capacity’, Petroleum Technology Development Journal (2), p.7.

Agbu, O., (2007), The Iron and Steel Industry and Nigeria's Industrialization: Exploring Cooperation with Japan (Institute of Developing Economies, Japan External Trade Organization: Japan).

Agreement on Safeguards (1994).

Akindelano LP, 'Review of Nigeria's Local Content Legislation', p.1, available at $<$ http://www.akindelano.com/dl/OD\%2520-

$\% 2520$ Local $\% 2520$ Content $\% 2520$ Act.pdf $>$.

Alford, R. P., (2011) ‘The Self-Judging W'TO Security Exception’, Utah Law Review, No.3, pp. 697-759.

Appellate Body Report (1999), Argentina - Safeguard Measures on Imports of Footwear, AB1999-7, WT/DS121/AB/R at paragraph 91.

Appellate Body Report (1999), Korea - Definitive Safeguard Measure on Imports of Certain Dairy Products, W'T/DS98/AB/R, (14 December 1999) at paragraph 84.

Appellate Body Report (2003), United States - Definitive Safeguard Measures on Imports of Certain Steel Products, WT/DS248/AB/R, WT/DS249/AB/R, WT/DS251/AB/R, WT/DS252/AB/R, WT/DS253/AB/R, WT/DS254/AB/R, WT/DS258/AB/R, WT/DS259/AB/R, (10 November, 2003) at paragraphs 276, 279, 296, 376, 383, 399, 452, $461,472,473,474,482,487,513$ (a) and (b).

Appellate Body Report (2013), Canada - Certain Measures Affecting the Renewable Energy Generation Sector, WT/DS412/AB/R.

Ayine, D., (2012), Consolidated Report on Proposed Petroleum Bills and Local Content Policy for the Petroleum Sector (A report submitted to the Ghana Research and Advocacy Programme (G-RAP), Accra, Ghana), p.47.

Balouga, J., (2012), 'Nigerian Local Content: Challenges and Prospects', International Association for Energy Economics, pp.23-26.

Binuomote S. O., and Odeniyi K. A., (2013), 'Effect of Crude Oil Price on Agricultural Productivity in Nigeria (1981-2010)', International Journal of Applied Agricultural and Apicultural Research, Vol. 9 (1\&2), pp. 131-138.

Canada - Administration of the Foreign Investment Review Act, Report of the Panel adopted on 7 February 1984 (L/5504 - 30S/140).

Canada - Measures Relating to the Feed - in Tariff Program, WT/DS426/AB/R (6 May, 2013).

Foundation for Environmental Security and Sustainability, Oil and Gas and Conflict Development Challenges and Policy Approaches (Foundation for Environmental Security and Sustainability and United States Agency for International Development: United States, January 2006) pp.7-8. 
General Agreement on Tariffs and Trade (GATT), TS 56 (1996) Cm 3282; 33 ILM 28 (1994). Hahn, M. J., (1991), 'Vital Interests and the Law of GATT: An Analysis of GAT'T's Security Exception', Michigan Journal of International Law, Vol. 12(3), pp.558-620.

Iledare W. and Suberu R., (2010), 'Oil and Gas Resources in the Federal Republic of Nigeria', Conference Proceedings: The Management of Oil and Oil and Gas in Federal Systems (World Bank and Forum of Federations: Washington, D.C.).

IMF, (2017), Nigeria - Selected Issues, IMF Country Report No. 17/81 (IMF: Washington, D.C), p.6.

IMF, (2019), Nigeria - Selected Issues, IMF Country Report No. 19/93 (IMF: Washington, D.C, April, 2019), p.5.

India - Measures Affecting the Automotive Sector, WT/DS146/R, WT/DS175/R and corr. 1, adopted 5 April 2002: V. 1827.

Mähler, A., (2010) Nigeria: A Prime Example of the Resource Curse? Revisiting the Oil Violence Link in the Niger Delta (German Institute of Global and Area Studies Working Papers: Germany) p. 120.

Mohammed, K.A., (2009) 'Nigerian Content Development: The Petroleum Technology Development Fund Initiatives', Petroleum Technology Development Journal, Vol. 2.

National Bureau of Statistics, (2013) Measuring Better: Frequently Asked Questions on the Rebasing / Re-Benchmarking of Nigeria's Gross Domestic Product (GDP) (National Bureau of Statistics: Abuja), p.13.

Nigerian Oil and Gas Industry Content Development Act (March, 2010).

Nwaokoro, Joseph E., (2011), 'Nigeria’s National Content Bill: The Hype, the Hope and the Reality', Journal of African Law, pp.128-155.

Nwaokoro, Joseph E., (2011), 'Signed, Sealed but will it Deliver? Nigeria's Local Content Bill and Cross-Sectoral Growth', The Journal of World Energy Law \&Business, pp.40-67.

Ogunyomi, G., et al, (2010), 'Overview of the Nigerian Content Development Act 2010', Aina Blankson LP Newsletter, p.2.

Orji, U.J, (2017a) 'The WTO Agreement on Subsidies and the Fiscal Incentive Regime under the Nigerian Local Content Act: a Compatibility Assessment', International Energy Law Review (2017) Vol. 35, Issue 5, pp.143-147.

Orji, U.J., (2017b) 'Assessing the Conformity of Nigeria's Local Content Act with GATS Obligations', International Trade Law \& Regulation (2017) Vol. 23, Issue 1, pp.12-24.

Orji, U.J., (2014), 'Towards Sustainable Local Content Development in the Nigerian Oil and Gas Industry: An Appraisal of the Legal Framework and Challenges Pt I', International Energy Law Review (2014) Vol. 32, Issue 1, p.41.

Orji, U.J., (2014), 'Towards Sustainable Local Content Development in the Nigerian Oil and Gas Industry: An Appraisal of the Legal Framework and Challenges Pt II', International Energy Law Review (2014) Vol. 32, Issue 2, pp.68-75.

Orji, U.J., (2018a) 'The Nigerian Oil and Gas Local Content Regime and its (Non-) Compliance with the TRIMS Agreement', Afe Babalola University Journal of Sustainable Development Law \& Policy (2018) Vol. 9, Issue 2, p.157.

Orji, U.J., (2018b) 'Promoting Technology Transfers in Nigeria's Extractive Industries: A Review of the Legal Regime, the Challenges and Proposals for Responses', Journal of World Trade and Investment (2018) 19(2) 248-292. 
Uchenna Jerome Orji

The Nigerian Oil and Gas Industry Content Development Act and GATT Treaty Obligations: On a Path of Harmony or Discord?

Proshare, (2017), Evaluating the Adequacy of Nigeria's External Reserves Level, available at $<$ https://www.proshareng.com/news/Nigeria\%20Economy/Evaluting-The-Adequacyof-Nigeria's-External-Reserves-Level/36781>.

Report on the Withdrawal by the United States of a Tariff Concession under Article XIX of the General Agreement on Tariffs and Trade (October, 1951) at paragraph 9.

SNF, Enhancement of Local Content in the Upstream Oil \& Gas Industry in Nigeria, SNF Report (2003) cited in Mohammed, K.A., 'Nigerian Content Development: The Petroleum Technology Development Fund Initiatives', Petroleum Technology Development Journal (July, 2009) Vol. 2,p.2.

The Blacks' Law Dictionary (8th Edition), p. 1535.

UNDP, Human Development Report 2015 (UNDP: New York, USA, 2015) pp.61 \&219.

United Nations Conference on Trade and Development (UNCTAD), Elimination of TRIMS: The Experience of Selected Developing Countries (United Nations: New York and Geneva, 2007) 9-10.

United Nations Development Programme (UNDP), Human Development Report 2016: Human Development for Everyone (UNDP: New York, USA, 2016), p.219.

United Nations Development Programme (UNDP), Human Development Report 2016: Human Development for Everyone (UNDP: New York, USA, 2016), pp.200, 204,208, 212, 216, $\& 271$.

United Nations, (2014), 'Country Classification', available at <https://www.un.org/en/ development/desa/policy/wesp/wesp_current/2014wesp_country_classification.pdf $>$.

United States - Measures Affecting the Importation, Internal Sale and Use of Tobacco, Report of the Panel adopted by the Council on 4 October 1994 (DS44/R).

United States Energy Information Administration, Nigeria', (26 May, 2016), available at $<$ https://www.eia.gov/beta/international/analysis.php?iso=NGA $>$.

Vaaland, T.I., et al, (2012), 'Local Content and Struggling Suppliers: A Network Analysis of Nigerian Oil and Gas Industry', African Journal of Business Management, Vol.6 (15), pp.5404-5405.

World Bank Macroeconomic and Fiscal Management Global Practice (Nigeria Team) (2017), Nigeria Bi-Annual Economic Update: Fragile Recovery, No. 1 (World Bank: Washington, D.C), p.15.

WTO - Committee on Trade-Related Investment Measures, Nigeria - Certain Measures Taken in the "Act to Provide for the Development of Nigerian Content in the Nigeria Oil and Gas Industry" of April 2010', Minutes of Meeting of the WTO Committee on TradeRelated Investment Measures held on 16 April, 2015 (G/TRIMS/M/38) (27 July, 2015), at paragraphs 111-117.

WTO - Committee on Trade-Related Investment Measures, Nigeria - Certain Measures Taken in the "Act to Provide for the Development of Nigerian Content in the Nigeria Oil and Gas Industry" of April 2010', Minutes of Meeting of the WTO Committee on TradeRelated Investment Measures held on 30 April, 2013 (G/TRIMS/M/34) (19 June, 2013), at paragraphs 56-62.

WTO Legal Affairs Division, (2012) WTO Dispute Settlement One Page Case Summaries 19952011 (WTO: Geneva) p.60. 
WTO Panel Report, Argentina - Definitive Safeguard Measure on Imports of Preserved Peaches, WT/DS238/R, (14 February 2003) adopted on 15 April 2003, DSR 2003:III, 1037.

WTO Panel Report, Canada - Certain Measures Affecting the Renewable Energy Generation Sector, WT/DS426/R (19 December, 2012).

WTO, Nigeria and the WTO', available at $<$ https://www.wto.org/english/thewto_e/countries_e/ nigeria_e.htm>.

WTO, WTO Analytical Index Guide to WTO Law and Practice - GATT 1994, XXI. Article XIX, Paragraph $\mathrm{B}$ at $816, \quad$ available at $<$ https://www.wto.org/english/res_e/booksp_e/analytic_index_e/ analytic_index_e.htm>.

\section{(c) (1) ()}

(c) Open Access This article is licensed under a Creative Commons Attribution-Non Commercial 4.0 International License, which permits the use, adaption and sharing as long as you give appropriate credit to the original author(s) and the source. The images or other third party material in this article are included in the article's Creative Commons license, unless indicated otherwise in a credit line to the material. If materials are not included in the article's Creative Commons license and your intended use is not permitted by statutory regulation or exceeds the permitted use, you will need to obtain permission directly from the copyright holder.

To view a copy of this license, visit http://creativecommons.org/licenses/by-nc/4.0/.

(C) The Author(s) 2020. 